${ }^{3}$ FREEMAN, T. N. 1939. Notes on the distribution of Plebeius aquilo Bdv. with the description of a new race from Manitoba (Lepid., Lycaenidae). Canadian Entomologist 71: 178-180.

${ }^{9}$ HOWE, W. H. (ed.). 1975. The butterflies of North America. Doubleday, Garden City, N.Y.

${ }^{10}$ MASTERS, J.H. 1974. Biennialism in Oeneis macounii (Satyridae). Journal of the Lepidopterists' Society 28(3): 237 242.

McDUNNOUGH, J. 1934. Notes on Canadian diurnal lepidoptera. Canadian Entomologist 66: 81-87.

${ }^{2}$ MILLER, L. D. and F. M. BROWN. 1981. A catalogue/checklist of the Rhopalocera of America north of Mexico. Lepitopterists' Society, Memoir 2.

3 PHILIP, K. W. 1974. The 1973 Field Season Summary, Zone 8. The Far North. Alaska and Northern Canada. News of the Lepidopterists Society No. 2, 1974: 14-15.

${ }^{4}$ RAUP, H.M. 1935. Botanical investigations in Wood Buffalo Park. Nat. Museum Canada, Bull. 74.

${ }^{5}$ REIST, J. D. 1979. Callophrys niphon (Lycaenidae) in Alberta with notes on the identification of $C$. niphon and $C$. eryphon. Journal of the Lepidopterists' Society 33(4): 248-253.

RYAN, J.K., and G. J. HILCHIE. 1981. Report on an Ecological Survey of terrestrial insect communities in the AOSERP study area. Prep. for Alberta Oil Sands Environmental Research Program by McCourt Management Ltd. AOSERP Report 115. 202 pp.

THOMPSON, M. D., M. C. WRIDE and M. E. KIRBY, 1978. Habitat mapping of the AOSERP study area: Phase 1. Prep. for the Alberta Oil Sands Environmental Research Program by Intera Environmental Consultants Ltd. AOSERP Report 31. $134 \mathrm{pp}$.

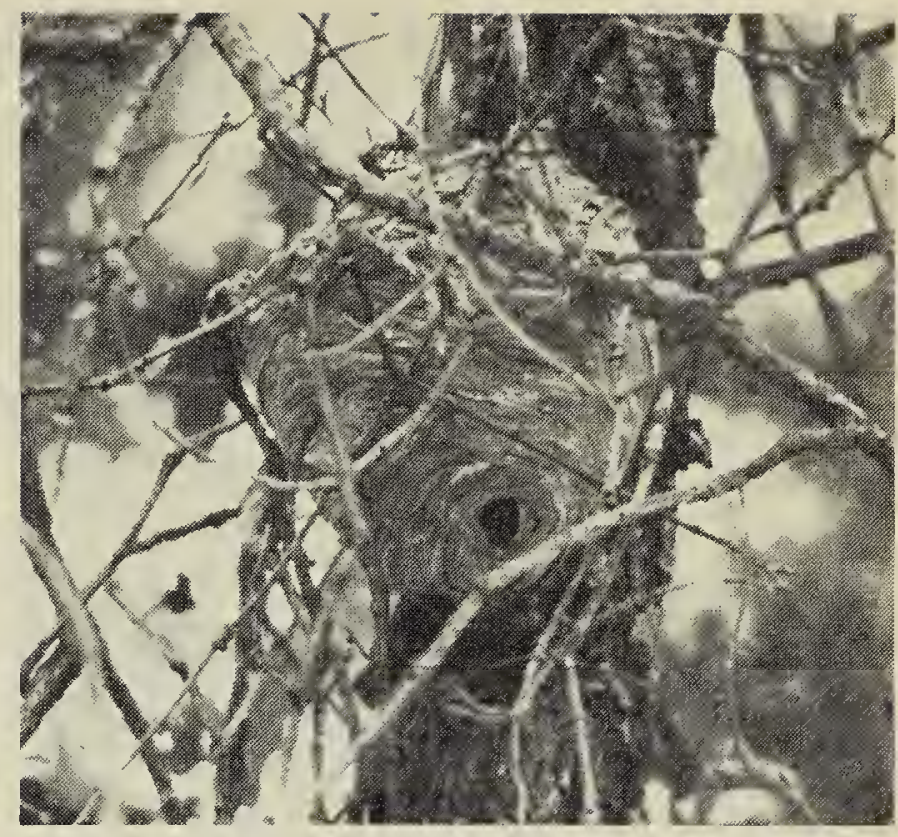

Hornet nest.

B. de Vries

\section{WHITE FACED QUEEN WASP ATTACKS CRANE FLY AT THE PAS}

WALTER KRIVDA, P.O. Box 864, The Pas, Manitoba. R9A $1 \mathrm{~K} 8$

At 8:00 a.m. on 17 June 1982 it was clear, sunny and warm. I observed a white faced wasp pounce on a newly emerged crane fly (tipulidae) on the south side of the house. The wasp flew ahead a bit first, having spotted the crane fly on the wall drying its wings. It then backed up while in flight without turning and swiftly pounced on its prey. Both fell to the ground and rolled around with the wasp making attempts to sting. They were briefly out of view having fallen into a bed of flowering Iris. A moment late the wasp flew up holding the crane fly between her legs, the head foremost and the abdomen hanging between the wasp's legs

In these parts, it is only the females or Queens which overwinter and start their paper nests in early spring. A proteinrich diet may be required to promote rapid growth of the larvae enabling the swift increase in wasp numbers that occurs in our brief summers. 